\title{
FERN SPORE BANK AT PEDREGULHO (ITIRAPINA, SÃO PAULO, BRAZIL)
}

\author{
SIMABUKURO, E. A., BEGOVACZ, A., ESTEVES, L. M. and FELIPPE, G. M. \\ Instituto de Botânica de São Paulo, C.P. 4005, CEP 01061-970, São Paulo, SP, Brazil \\ Correspondence to: Luciano M. Esteves, Instituto de Botânica de São Paulo, C.P. 4005, CEP 01061-970, \\ São Paulo, SP, Brazil, e-mail: luciano@mandic.com.br \\ Received April 06, 1998 - Accepted August 21, 1998 - Distributed February 23, 1999
}

(With 1 figure)

\begin{abstract}
This paper presents an analysis of pteridophyte spore bank the site of Pedregulho, in Itirapina, state of São Paulo, Brazil. The samples of soil were collected in February (rainy season) and August (dry season) in four localities: open cerrado, cerradão, gallery forest and a disturbed area at depths of $0-5,5-10$ and $10-15 \mathrm{~cm}$.

The samples were collected in duplicate. Of the duplicates, one was used for spore counting and the second one for spore germination. In the cerrado, cerradão and gallery forest soil samples the values for pteridophyte spores were similar in the rainy and dry season, but in the disturbed area the percentage of spores was higher in the rainy season than in the dry season. The number of pteridophyte spores decreased with soil depth in the rainy season in the cerrado, cerradão and disturbed area. Gametophytes were found in all samples. In general, soil collected in the cerrado, cerradão and disturbed area in the dry season presented more gametophytes than the ones collected in the rainy season. The number of gametophytes was lower in the $10-15 \mathrm{~cm}$ deep samples. The present results clearly show a reserve of spores in the soil of the four different sites studied in Itirapina region, in Brazil. Thus in this region turning over of soil layers and other kinds of disturbance can bring spores to the soil surface and their germination. This is one of the first reports of a pteridophyte spore bank for Brazil, no mention of any pteridophyte spore bank is made for South America by Lindsay \& Dyer (1990) and Dyer \& Lindsay (1992).
\end{abstract}

Key words: fern spore bank, gametophytes, cerrado, cerradão, gallery forest, Brazil.

\section{RESUMO}

\section{Banco de esporos de pteridófitas do Pedregulho (Itirapina, São Paulo, Brasil)}

Neste trabalho é apresentada uma análise do banco de esporos de pteridófitas do Pedregulho, em Itirapina, SP, Brasil. As amostras dos solos foram coletadas em fevereiro (estação chuvosa) e agosto (estação seca) de 1996, nas profundidades de 0-5, 5-10 e 10-15 cm. As amostras foram coletadas no cerrado, cerradão, mata ciliar e em uma área perturbada, em duplicata.

Da duplicata, uma amostra foi usada para contagem do número de esporos e a segunda, para a germinação dos esporos e posterior contagem de gametófitos. Os valores em número de esporos de pteridófitas foi semelhante nas estações seca e chuvosa para cerrado, cerradão e mata ciliar. Na área perturbada, a porcentagem de esporos foi maior na estação chuvosa do que na seca. O número de esporos de pteridófitas decresceu com o aumento em profundidade (isto é, quanto mais profunda a camada, menor o número de esporos) na estação chuvosa no cerrado, cerradão e área perturbada. Foram encontrados gametófitos em todas as amostras. Em geral, solos coletados no cerrado, cerradão e área perturbada na estação seca apresentaram mais gametófitos do que nos solos coletados na estação chuvosa. O número de gametófitos foi menor nas amostras coletadas a 10-15 cm de profundidade. Os 
resultados deste trabalho claramente mostram que uma reserva de esporos de pteridófitas existe nos solos das quatro áreas estudadas na região de Itirapina, Brasil. Esta é uma das primeiras menções de um banco de esporos de pteridófitas em solos para o Brasil nenhum banco de esporos de pteridófitas foi mencionado para a América do Sul por Lindsay \& Dyer (1990) and Dyer \& Lindsay (1992).

Palavras-chave: banco de esporos de pteridófitas, gametófitos, cerrado, cerradão, mata ciliar, Brasil.

\section{INTRODUCTION}

In areas in which it is desirable to recover the original vegetation it is very important to study soil spore and seed banks. Soil spore banks are of interest because of their potential as a resource for in situ restoration of dwindling, or even extinct, populations. In principle, it should be possible to induce establishment of new plants in situ from existing natural soil spore banks (Dyer \& Lindsay, 1996). However, only species in which germination can be delayed and viability of the propagules maintained will be found in soil banks (Hamilton, 1988). Miller (1968) showed that the majority of species of pteridophyte studied have light sensitive spores. All the species studied from the Brazilian cerrado and from a gallery forest in Brazil have light sensitive spores (Esteves \& Felippe, 1985, Simabukuro et al., 1993). This characteristic of a great number of pteridophyte spores is one of the main factors for pteridophyte (fern) spore soil bank formation, as the spores germinate only when they are brought to the soil surface.

As natural soil spore banks have considerable potential as a source of conservation material (Dyer, 1994), this work was carried out with different soil samples from Pedregulho, a site in Itirapina, Southeast Brazil, to see if spore banks were present. This is the first work on pteridophyte spore bank carried out in Brazil.

\section{MATERIAL AND METHODS}

The study was carried out at Pedregulho in the Estação Experimental de Itirapina, state of São Paulo, Brazil $\left(22^{\circ} 51^{\prime} \mathrm{S}\right.$ and $\left.47^{\circ} 52^{\prime} \mathrm{W}\right)$. A floristic survey was carried out in the cerrado area of the Estação Experimental de Itirapina (Gianotti \& Leitão-Filho, 1992). The climate is mesothermic, with a dry winter, presenting an annual water deficit of $23 \mathrm{~mm}$. A total of 118 species of angiosperms, 87 genera and 26 families were sampled by Gianotti
\& Leitão Filho (1992). Only nine species of ferns were collected in the cerrado (Esteves \& Felippe, 1985 ) and a total of 40 species when the gallery forest was considered (Simabukuro et al., 1998a). The soil samples were collected in four sites in the Pedregulho locality: gallery forest, cerrado, cerradão and disturbed area (in a depression near the gallery forest with plants from the cerrado and invaders like weeds) at depths of 0-5, 5-10 and $10-15 \mathrm{~cm}$. The chemical and physical analyses of these samples are presented in Tables 1 and 2. The samples were collected in the rainy (February) and dry (August) seasons of 1996. Fig. 1 presents the rainfall and the temperature of the region in the period of the experiment. The samples were collected in duplicate with a $56.7 \mathrm{~cm}^{3}$ metal cylinder with $5 \mathrm{~cm}$ bore diameter (Endecott - EFL1 $\mathrm{mk} 3$ ). Thus, in each case, a vertical core was taken and subdivided in the three portions for the three depths analysed. Of the duplicates, one was used for spore counting and the second one for spore germination.

\section{Number of spores}

The soil was treated by a modification of the method described by Ybert et al. (1992). Aliquots of $10 \mathrm{~g}$ of each sample were treated for two hours with hydrochloric acid. After discarding the supernatant (10 min centrifugation at $482 \mathrm{xg}$ ) the material was kept for six days in hydrofluoric acid. The hydrofluoric acid was eliminated by dilution in water (1:2 - acid:water) and then centrifuged (10 $\mathrm{min}$ at $482 \mathrm{xg}$ ). The fluosilicates were removed by treatment with $32 \%$ hydrochloric acid during one hour and washing and centrifugation (10 min at 482 $\mathrm{xg}$ ) three times with hot distilled water followed by filtration through a mesh $(0.177 \mathrm{~mm}$ pore diameter). The material retained in the filter was treated for $5 \mathrm{~min}$ with concentrated nitric acid. After centrifugation (10 min at $482 \mathrm{xg}$ ) the precipitate was washed three times with distilled water and then mixed with $50 \%$ hydrochloric acid. The hydrochloric acid mixture was centrifuged (10 $\mathrm{min}$ at $482 \mathrm{xg}$ ). 
The precipitate was then washed with zinc chloride. This mixture was separated in two liquid phases with $20 \mathrm{~min}$ centrifugation at $482 \mathrm{xg}$ and the upper phase was collected. The precipitate was washed again with zinc chloride and the whole proceeding repeated. The two upper phases obtained were diluted in $95 \%$ ethanol (2:3 - zinc chloride:ethanol). After centrifugation (10 $\mathrm{min}$ at $482 \mathrm{xg}$ ) the precipitate was washed with $50 \%$ hydrochloric acid (and centrifuged for $10 \mathrm{~min}$ at $482 \mathrm{xg}$ ) followed by washing three times with distilled water and centrifugation (10 $\mathrm{min}$ at 482 $\mathrm{xg})$.

The precipitate was transferred to acetic acid in centrifuge tubes which is the first step of the acetolysis method (Erdtman, 1971). From the concentrated material in the centrifuge tubes samples of grains were transferred with the help of gelatin-glycerin to microscope slides where the grains were counted. The slides were gelatin-glycerin mounted according to Kisser (in Erdtman, 1971). A total of 500 grains (spores + pollen) were always counted. To be able to count 500 grains (pteridophyte spores + bryophyte spores + pollen), five to seventeen microscope slides were used; normally fewer slides were used with the superficial soil samples. More slides were needed when the material was poor in grains; thus Table 3 gives an idea of how rich in grains was the material from each site. The percentage of pteridophyte spores was calculated in relation to the total 500 grains (pollen + bryophyte spores + pteridophyte spores). It was impossible to identify to species most of the fern spores. Both a checklist of ferns and a morphological study of the fern spores for the Pedregulho site of Estação Experimental de Itirapina are not available. In some instances fern spores were compared with material identified previously by us in the survey carried out in the Reserva Biológica e Estação Experimental de Moji Guaçu (Simabukuro et al., 1998a). The pollen grains and bryophyte spores were not identified by us. However, the slides are permanent and kept in the laboratory for future use when needed.

\section{Spore germination}

As mentioned before, the second replicate (a $15 \mathrm{~cm}$ long vertical core) was subdivided in the three portions for the three depths analysed (0-5, 5-10 and 10-15 cm deep). Each of these portions was placed over washed sand in three Petri dishes ( $5 \mathrm{~cm}$ diameter) which provides a total area of $60 \mathrm{~cm}^{2}$. Each Petri dish received a layer of washed autoclaved sand mixed with imbibed gelatin. The gelatin was used after trying different ways of keeping the moisture of the soil: the use of gelatin was very efficient. The imbibed gelatin was prepared with $5 \mathrm{~g}$ of gelatin mixed in $300 \mathrm{ml}$ of distilled water. Over the mixture sand-gelatin was placed a layer of $5 \mathrm{~mm}$ deep of each soil (as recommended by Wesson \& Wareing, 1969). Then distilled water was added to the soil and the Petri dish was sealed with parafilm. The dishes were kept in growth cabinets at constant $25^{\circ} \mathrm{C}$ and continuous white light at $437 \mathrm{~mW} \cdot \mathrm{cm}^{-2} \cdot \mathrm{s}^{-1}$ at Petri dish level (Ruggiero \& Zaidan, 1997). The number of two-dimensional gametophytes was counted two and four months from the beginning of the germination experiment using a stereomicroscope. At the moment the gametophytes cannot be identified to species as no published work exists. A long term work is being carried out to provide an identification key for the different species of gametophytes of the species present both at Pedregulho (Itirapina) and at the Reserva Biológica e Estação Experimental de Moji Guaçu, Moji Guaçu, state of São Paulo. It has been shown in all the species studied that trichomes are very useful for identification purposes: all the species studied can be divided in two groups: gametophytes with trichomes and gametophytes without trichomes (Láquila \& Esteves, 1997). Because of these findings and also according to Dyer \& Lindsay (1992) the gametophytes were divided into $\mathrm{T}^{+}$ (gametophytes with trichomes) and $\mathrm{T}^{-}$(gametophytes without trichomes). The results are presented as the total number of gametophytes per $\mathrm{cm}^{2}$.

\section{RESULTS AND DISCUSSION}

The soil of the cerradão has less organic matter than the soils of the gallery forest and the cerrado. The soil of the gallery forest is the richest in organic matter and phosphorus. With the exception of the soil from the cerradão in all sites studied the level of organic matter decreased with depth (Table 1). The cerrado soils are known to be acid (Goodland, 1971a, Malavolta et al., 1977). In the samples used here the soil was acid in the four sites where the soil banks were studied and acidity was very similar at all depths (Table 1). The main sources of acidity are minerals from the aluminum silicate clay which liberate aluminium 
ions according to the $\mathrm{pH}$ (Goodland, 1971b). In the present case the level of $\mathrm{Al}^{3+}$ was very high in all samples and the level was higher in the gallery forest and cerrado than in the cerradão and disturbed area soils. The soil texture can be judged from Table 2. The amount of sand is very high in the three depths studied in cerradão, mainly fine sand. The gallery forest presents has sand than the cerrado. The amount of sand in the four sites studied is very similar in the three depths studied. The amounts of silt were higher in the disturbed area samples when compared to the cerradão site. The amount of clay was similar in the cerrado and disturbed area sites. Only the samples from the cerradão were sandy soils.

The percentage of spores of pteridophytes in relation to the total number of 500 grains (pollen + bryophyte spores + pteridophyte spores) counted in the microscope slides is shown in Table 3. This gives relative numbers which are very useful to compare the different sites tested. In the disturbed area the percentage of spores was higher in the rainy season than in the dry season; in the cerrado, cerradão and gallery forest samples the values were similar in both seasons. The highest percentages of spores were found in the disturbed area in the rainy season and higher percentage of spores was found in this season in the gallery forest than in the cerrado and cerradão. The soils were collected in the beginning of February (rainy season) after a very rainy and hot January (Fig. 1). During this season the spores from cerrado and cerradão are washed by the heavy rain into the gallery forest and mainly to the disturbed area, which is located in a depression in relation to the cerrado and cerradão. The percentage of spores decreased significantly in the disturbed area in the dry season, but in this case the soil was collected in the beginning of August, after a July with the lowest temperatures of the year and no rain at all (Fig. 1). In general higher percentage of spores (relative numbers) were found in the gallery forest than in the cerrado and cerradão in both seasons. The percentage of spores decreased with depth in the rainy season in the cerrado, cerradão and disturbed area and only in the disturbed area in the dry season.

TABLE 1

Chemical analysis of the soil samples from Pedregulho (Itirapina, São Paulo, Brazil), according to the Departamento de Ciências do Solo, Universidade de São Paulo, Piracicaba, SP.

\begin{tabular}{|c|c|c|c|c|c|c|c|c|c|c|c|c|c|}
\hline Sample & $\begin{array}{l}\text { Depth } \\
(\mathrm{cm})\end{array}$ & $\begin{array}{c}\text { Presin } \\
(\mu \mathrm{g} . \mathrm{cm}-3)\end{array}$ & $\begin{array}{l}\mathrm{OM} \\
(\%)\end{array}$ & $\mathrm{pHCaCl}_{2}$ & \multicolumn{7}{|c|}{ (meq. $100 \mathrm{~cm} 3)$} & $\begin{array}{c}\mathrm{V} \\
(\%)\end{array}$ & $\begin{array}{c}m \\
(\%)\end{array}$ \\
\hline \multirow[t]{3}{*}{ Cerrado } & $0-5$ & 9 & 4.9 & 3.6 & 0.19 & 0.5 & 0.4 & 1.4 & 10.9 & 1.1 & 12.0 & 9 & 56 \\
\hline & $5-10$ & 6 & 3.0 & 3.8 & 0.15 & 0.2 & 0.2 & 1.2 & 8.8 & 0.6 & 9.4 & 6 & 67 \\
\hline & $10-15$ & 4 & 2.5 & 3.9 & 0.16 & 0.1 & 0.2 & 0.7 & 8.0 & 0.5 & 8.5 & 6 & 58 \\
\hline \multirow[t]{3}{*}{ Cerradão } & $0-5$ & 5 & 1.4 & 4.2 & 0.27 & 0.4 & 0.4 & 0.3 & 2.2 & 1.1 & 3.3 & 33 & 21 \\
\hline & $5-10$ & 2 & 1.3 & 3.9 & 0.13 & 0.3 & 0.3 & 0.7 & 2.8 & 0.7 & 3.5 & 20 & 50 \\
\hline & $10-15$ & 3 & 1.0 & 4.0 & 0.08 & 0.2 & 0.2 & 0.4 & 1.8 & 0.5 & 2.3 & 22 & 44 \\
\hline Gallery & $0-5$ & 20 & 6.7 & 4.1 & 0.35 & 3.6 & 1.9 & 1.1 & 13.5 & 5.9 & 19.4 & 30 & 16 \\
\hline \multirow[t]{2}{*}{ forest } & $5-10$ & 20 & 5.7 & 3.9 & 0.25 & 1.3 & 0.8 & 2.0 & 15.0 & 2.4 & 17.4 & 14 & 45 \\
\hline & $10-15$ & 19 & 4.7 & 3.9 & 0.11 & 0.5 & 0.3 & 2.2 & 13.5 & 0.9 & 14.4 & 6 & 71 \\
\hline Disturbed & $0-5$ & 7 & 3.0 & 4.0 & 0.10 & 0.4 & 0.3 & 0.4 & 5.8 & 0.8 & 6.6 & 12 & 33 \\
\hline \multirow[t]{2}{*}{ area } & $5-10$ & 4 & 1.8 & 4.4 & 0.13 & 0.3 & 0.5 & 0.3 & 3.8 & 0.9 & 4.7 & 19 & 25 \\
\hline & $10-15$ & 6 & 1.4 & 4.5 & 0.05 & 0.2 & 0.2 & 0.2 & 3.1 & 0.5 & 3.6 & 14 & 29 \\
\hline
\end{tabular}

$\mathrm{OM}$ : organic matter; $\mathrm{H}^{+}+\mathrm{Al}^{3+}$ : potential acidity; $\mathrm{SB}$ : sum of bases $=\mathrm{Ca}^{2+}+\mathrm{Mg}^{2+}+\mathrm{K}^{+} ; \mathrm{CEC}$ : cationic exchange capacity $=\mathrm{SB}+\left(\mathrm{H}^{+}+\mathrm{Al}{ }^{3+}\right)$ $\mathrm{V}$ : saturation of bases $=\mathrm{SB} . \mathrm{CEC}^{-1}$. $100 ; \mathrm{m}$ : saturation of $\mathrm{Al}^{3+}=\mathrm{Al} \times(\mathrm{SB}+\mathrm{Al})^{-1} \times 100$. 
TABLE 2

Physical analysis of the soil samples from Pedregulho (Itirapina, São Paulo, Brazil), according to the Departamento de Ciências do Solo, Universidade de São Paulo, Piracicaba, SP.

\begin{tabular}{|c|c|c|c|c|c|c|c|c|c|c|}
\hline \multirow[t]{2}{*}{ Sample } & \multirow{2}{*}{$\begin{array}{c}\text { Depth } \\
\text { (cm) }\end{array}$} & \multicolumn{6}{|c|}{ Sand $(\%)$} & \multirow{2}{*}{$\begin{array}{l}\text { Silt } \\
(\%)\end{array}$} & \multirow{2}{*}{$\begin{array}{c}\text { Clay }(\%) \\
\text { tot }\end{array}$} & \multirow[t]{2}{*}{ Texture class } \\
\hline & & ve & c & $\mathbf{m}$ & f & $\mathbf{v f}$ & tot & & & \\
\hline \multirow[t]{3}{*}{ Cerrado } & $0-5$ & 2 & 7 & 13 & 20 & 4 & 46 & 12 & 42 & clayey \\
\hline & $5-10$ & 1 & 5 & 12 & 22 & 3 & 43 & 13 & 44 & clayey \\
\hline & $10-15$ & 2 & 4 & 10 & 21 & 4 & 41 & 10 & 49 & clayey \\
\hline \multirow[t]{3}{*}{ Cerradão } & $0-5$ & 1 & 8 & 25 & 40 & 6 & 80 & 4 & 16 & m-sandy \\
\hline & $5-10$ & 1 & 7 & 24 & 40 & 4 & 76 & 6 & 18 & m-sandy \\
\hline & $10-15$ & 1 & 6 & 33 & 43 & 3 & 86 & 4 & 10 & sandy \\
\hline Gallery & $0-5$ & 1 & 8 & 19 & 19 & 8 & 55 & 14 & 31 & m-clayey \\
\hline \multirow[t]{2}{*}{ forest } & $5-10$ & - & 7 & 19 & 21 & 8 & 55 & 12 & 33 & m-clayey \\
\hline & $10-15$ & - & 7 & 15 & 16 & 11 & 49 & 12 & 39 & clayey \\
\hline Disturbed & $0-5$ & 1 & 3 & 7 & 11 & 2 & 24 & 31 & 45 & clayey \\
\hline \multirow[t]{2}{*}{ area } & $5-10$ & 4 & 4 & 6 & 10 & 4 & 28 & 27 & 45 & clayey \\
\hline & $10-15$ & 1 & 5 & 7 & 14 & 6 & 33 & 24 & 43 & clayey \\
\hline
\end{tabular}

vc: very coarse; c: coarse; m: medium; f: fine; vf: very fine; tot: total ; -: not analysed or value zero.

\section{TABLE 3}

Percentage of spores of pteridophytes in relation to the total number of 500 grains counted for the soil samples of cerrado, cerradão, gallery forest and disturbed area at Pedregulho (Itirapina, São Paulo, Brazil), collected at three depths in the rainy and dry season.

\begin{tabular}{|c|c|c|c|}
\hline \multirow[t]{2}{*}{ Samples } & \multirow{2}{*}{$\begin{array}{c}\text { Depth } \\
\text { (cm) }\end{array}$} & \multicolumn{2}{|c|}{ Spores of pteridophyte as a \% of a total of 500 grains (pollen + spores) } \\
\hline & & Rainy season & Dry season \\
\hline \multirow[t]{3}{*}{ Cerrado } & $0-5$ & 3.0 & 1.0 \\
\hline & $5-10$ & 2.0 & 3.0 \\
\hline & $10-15$ & 1.2 & 2.0 \\
\hline \multirow[t]{3}{*}{ Cerradão } & $0-5$ & 2.4 & 3.0 \\
\hline & $5-10$ & 2.0 & 1.2 \\
\hline & $10-15$ & 0 & 2.0 \\
\hline \multirow[t]{3}{*}{ Gallery forest } & $0-5$ & 3.8 & 2.2 \\
\hline & $5-10$ & 5.0 & 7.0 \\
\hline & $10-15$ & 3.2 & 1.4 \\
\hline \multirow[t]{3}{*}{ Disturbed area } & $0-5$ & 52.4 & 10.2 \\
\hline & $5-10$ & 38.0 & 8.0 \\
\hline & $10-15$ & 18.0 & 5.0 \\
\hline
\end{tabular}



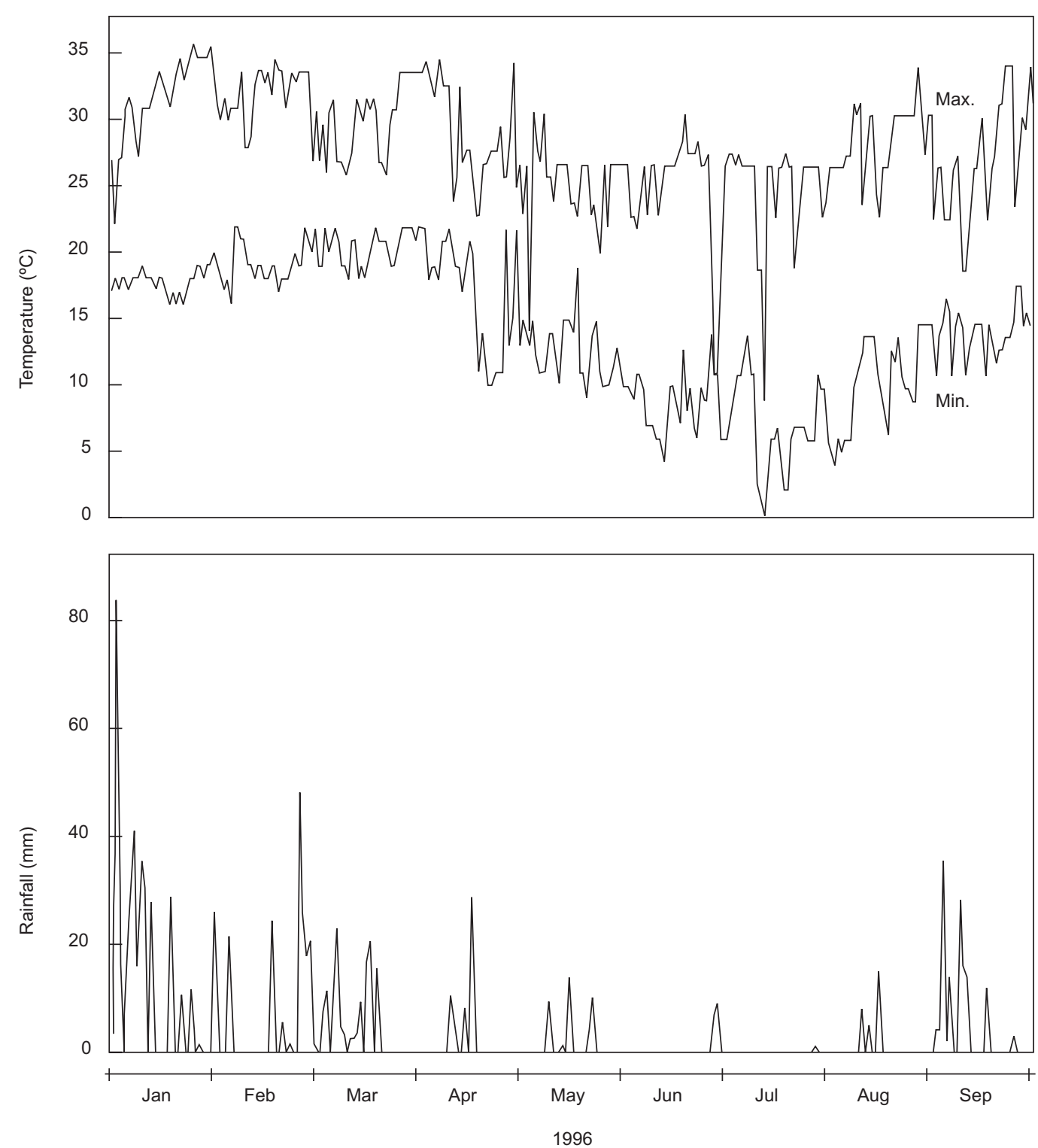

Fig. 1 - Temperature $\left({ }^{\circ} \mathrm{C}\right)$ and rainfall $(\mathrm{mm})$ between January and September 1996. Pedregulho (Itirapina, São Paulo, Brazil).

The objective here was not to identify species of pteridophytes but spores of Cyathea delgadii Sternb., Cyathea phalerata Mart. and Polypodium latipes Langsd. \& Fisch., were identified by comparison with the material studied by us from the Reserva Biológica e Estação Experimental de Mogi-Guaçu, Mogi-Guaçu (Simabukuro et al., 1998a). In the disturbed area Lycopodium clavatum L. spores were the most frequent $(82 \%$ in the rainy season and $79 \%$ of the total pteridophyte spores in the dry season).

No spores were found in the cerradão in the $10-15 \mathrm{~cm}$ deep sample in the rainy season. However, a few spores must be present as gametophytes were produced in another sample of the same region and same depth (Table 4). The number of gametophytes with trichomes, gametophytes without trichomes and the total number of gametophytes 
after two months from the beginning of germination experiments is shown in Table 4.

Gametophytes were found in all samples. In general, soil collected in the cerrado, cerradão and disturbed area in the dry season produced more gametophytes than the ones collected in the rainy season. However, in the gallery forest samples, more gametophytes were produced from soil samples collected in the rainy season than in the dry season. In general, the number of gametophytes with trichomes was higher than the ones without trichomes in the soil collected in the rainy sea-

TABLE 4

Number of gametophytes (total, $\mathbf{T}^{+}$and $\mathbf{T}^{-}$) per $\mathrm{cm}^{2}$ of soil from the cerrado, cerradão, gallery forest and disturbed area at Pedregulho (Itirapina, São Paulo, Brazil) ( 2 and 4 months from the beginning of the experiments). $\mathbf{T}^{+}$: gametophyte with trichomes; $\mathrm{T}^{-}$: gametophyte without trichomes.

\begin{tabular}{|c|c|c|c|c|c|c|c|}
\hline \multirow{4}{*}{ Sample } & \multirow{4}{*}{$\begin{array}{c}\text { Depth } \\
(\mathbf{c m})\end{array}$} & \multicolumn{6}{|c|}{2 months from the beginning of the germination experiment } \\
\hline & & \multirow{2}{*}{\multicolumn{3}{|c|}{$\begin{array}{c}\text { Rainy season } \\
\text { Number of gametophytes.cm }\end{array}$}} & \multirow{2}{*}{\multicolumn{3}{|c|}{$\begin{array}{c}\text { Dry season } \\
\text { Number of gametophytes.cm } \\
\end{array}$}} \\
\hline & & & & & & & \\
\hline & & $\mathbf{T}_{+}$ & $\mathbf{T}^{-}$ & Total & $\mathbf{T}_{+}$ & $\mathbf{T}_{-}$ & Total \\
\hline \multirow[t]{3}{*}{ Cerrado } & $0-5$ & 0.15 & 0.12 & 0.27 & 0.20 & 0.22 & 0.42 \\
\hline & $5-10$ & 0.05 & 0.15 & 0.20 & 0.07 & 0.15 & 0.22 \\
\hline & $10-15$ & 0.05 & 0.02 & 0.07 & 0 & 0 & 0 \\
\hline \multirow[t]{3}{*}{ Cerradão } & $0-5$ & 0.05 & 0 & 0.05 & 0.07 & 0.20 & 0.27 \\
\hline & $5-10$ & 0.05 & 0.03 & 0.08 & 0.08 & 0.32 & 0.40 \\
\hline & $10-15$ & 0 & 0.03 & 0.03 & 0.05 & 0.27 & 0.32 \\
\hline Gallery & $0-5$ & 4.23 & 0.72 & 4.95 & 0.73 & 2.50 & 3.23 \\
\hline \multirow[t]{2}{*}{ forest } & $5-10$ & 4.58 & 0.72 & 5.30 & 0.65 & 3.20 & 3.85 \\
\hline & $10-15$ & 2.38 & 0.17 & 2.55 & 0.18 & 1.97 & 2.15 \\
\hline Disturbed & $0-5$ & 0 & 0.08 & 0.08 & 0.20 & 0.25 & 0.45 \\
\hline \multirow[t]{2}{*}{ area } & $5-10$ & 0 & 0.03 & 0.03 & 0.07 & 0.15 & 0.22 \\
\hline & $10-15$ & 0 & 0 & 0 & 0.05 & 0 & 0.05 \\
\hline
\end{tabular}

\begin{tabular}{|c|c|c|c|c|c|c|c|}
\hline \multirow{4}{*}{ Sample } & \multirow{4}{*}{$\begin{array}{c}\text { Depth } \\
\text { (cm) }\end{array}$} & \multicolumn{6}{|c|}{4 months from the beginning of the germination experiment } \\
\hline & & \multirow{2}{*}{\multicolumn{3}{|c|}{$\begin{array}{c}\text { Rainy season } \\
\text { Number of gametophytes.cm }{ }^{-2}\end{array}$}} & \multirow{2}{*}{\multicolumn{3}{|c|}{$\begin{array}{c}\text { Dry season } \\
\text { Number of gametophytes.cm } \\
\end{array}$}} \\
\hline & & & & & & & \\
\hline & & $\mathbf{T}_{+}$ & $\mathbf{T}^{-}$ & Total & $\mathbf{T}^{+}$ & T- & Total \\
\hline \multirow[t]{3}{*}{ Cerrado } & $0-5$ & 0.25 & 0.30 & 0.55 & 0.22 & 0.28 & 0.50 \\
\hline & $5-10$ & 0.12 & 0.27 & 0.39 & 0.30 & 0.07 & 0.37 \\
\hline & $10-15$ & 0.10 & 0.10 & 0.20 & 0.07 & 0.08 & 0.15 \\
\hline \multirow[t]{3}{*}{ Cerradão } & $0-5$ & 0.05 & 0.05 & 0.10 & 0.12 & 2.22 & 0.34 \\
\hline & $5-10$ & 0 & 0 & 0 & 0.23 & 0.15 & 0.38 \\
\hline & $10-15$ & 0 & 0.15 & 0.15 & 0.05 & 0.23 & 0.28 \\
\hline Gallery & $0-5$ & 5.00 & 1.85 & 6.85 & 0.93 & 3.03 & 3.96 \\
\hline \multirow[t]{2}{*}{ forest } & $5-10$ & 3.47 & 0.60 & 4.07 & 0.58 & 2.77 & 3.35 \\
\hline & $10-15$ & 1.82 & 0.40 & 2.22 & 0.40 & 3.08 & 3.48 \\
\hline Disturbed & $0-5$ & 0.25 & 0.30 & 0.55 & 0.22 & 0.28 & 0.50 \\
\hline \multirow[t]{2}{*}{ area } & $5-10$ & 0.12 & 0.30 & 0.42 & 0.30 & 0.05 & 0.35 \\
\hline & $10-15$ & 0.17 & 0.10 & 0.27 & 0.07 & 0.08 & 0.15 \\
\hline
\end{tabular}


son, but in the dry season the number of gametophytes with trichomes was lower than the ones without trichomes. Soil from the gallery forest presented a much higher number of gametophytes than the soil from the other three sites. In general, in all sites the number of gametophytes was lower in the $10-15 \mathrm{~cm}$ deep sample. Lindsay \& Dyer (1990) suggested that the mineral nutrient deficiency of the deeper samples might be responsible for the delayed appearance of the gametophytes. This could be the case here as Table 1 shows the mineral contents of the soils from the four sites studied decreased from the $0-5 \mathrm{~cm}$ to the $10-15 \mathrm{~cm}$ deep samples. Table 4 also shows the presence of gametophytes four months from the beginning of the experiment. At this stage gametophytes were observed in all samples with the exception of the sample collected at $5-10 \mathrm{~cm}$ deep in the cerradão site in the rainy season. The differences in number of gametophytes produced in soil samples between rainy and dry season are less marked. Again, the number of gametophytes with trichomes was significantly higher than the ones without trichomes in the soil collected in the rainy season, but in the dry season the reverse occurred. Thus it seems that species of pteridohytes present in the rainy season were absent in the dry season, taking into account the findings of Láquila \& Esteves (1997) already mentioned. This points to the fact that the bank only lasts for six months. New gametophytes appeared and some died in the period between two and four months from the beginning of the germination experiment. Necrosis of gametophytes was observed to be higher in the gallery forest samples than in cerrado, cerradão and disturbed area, probably because of the great number of gametophytes present. The number of gametophytes increased in the soil from the cerrado, cerradão and disturbed area between the first and second examination of the Petri dishes. Lindsay \& Dyer (1990) observed that gametophytes appearing on the deeper soil samples develop more slowly than those on soil samples collected nearer the surface. They do not know the reason but say that one possibility could be the increased nutritional deficiency of the deeper soil samples. From the present results for two and four months it is not clear that the gametophytes from the $10-15 \mathrm{~cm}$ deep samples appear later than the more superficial layer. The disturbed area presents the highest percentage of spores of the four sites (Table 3), but a very small number of gametophytes when compared to the gallery forest (Table 4). Gametophyte densities were much higher in the samples from the gallery forest than from the other three sites. This is not surprising as the aboveground vegetation comprises much more species of pteridophyte in the gallery forest than the other three sites. During this work the following species were collected in the gallery forest: Anemia flexuosa (Sav.) Sw., A. phyllitidis (L.) Sw., A. raddiana Link, Blechnum brasiliense Desv. , B. glandulosum Link, B. occidentale L., B. polypodioides Raddi, Cyathea delgadii Sternb., C. phalerata Mart., Dicranopteris flexuosa (Schrad.) Underw., Elaphoglossum blanchetii (Mett.) C.Chr., E. cf. discolor (Kuhn) C.Chr., E. vagans (Met.) Heron, Lygodium venustum Sw., Microgramma squamulosa (Kaulf.) Sota, Osmunda regalis L., Pecluma filicula (Kaulf.) Price, Pleopeltis angusta Humb. \& Bonpl. ex Willd., Polypodium hirsutissumum Raddi, P. latipes Langsd. \& Fisch., P. polypodioides (L.) Watt. var. minus (Fée) Weath. and Salpichlaena volubilis (Kaulf.) Hook. In the cerrado and cerradão: Anemia flexuosa (Sav.) Sw., A. raddiana Link, Microgramma squamulosa (Kaulf.) Sota, Pleopeltis angusta Humb. \& Bonpl. ex Willd., Polypodium hirsutissumum Raddi, P. latipes Langsd. \& Fisch. and P. polypodioides (L.) Watt. var. minus (Fée) Weath. were present. Only Dicranopteris flexuosa (Schrad.) Underw., Lycopodium clavatum L. and Pteridum aquilinum (L.) Kuhn var. arachnoideum (Kaulf.) Kuhn were collected in the disturbed area.

Although few spores have been identified to species, the present results clearly show a reserve of spores in the soil of the four different sites in Itirapina region, in Brazil. Thus in this region turning over of soil layers and other kinds of disturbance can bring spores to the soil surface and their germination. A better correlation between the palynological analysis and diversity of species of the bank will be possible only when identification of gametophytes is done; this will be possible only when the work by Láquila \& Esteves (1997) is concluded. Table 4 showing two types of gametophytes gives an idea of diversity. This is one of the first report of a pteridophyte spore bank for Brazil, the other one relates to Moji Guaçu region (Simabukuro et al., 1998b), no mention of any pteridophyte spore bank is made for South America by Lindsay \& Dyer (1990) and Dyer \& Lindsay (1992). 
Acknowledgements - Thanks are due to Dr. Adrian F. Dyer (University of Edinburgh) for suggestions, discussing and correcting the English manuscript. Thanks are also due to the $\mathrm{CNPq}$ (Brazil) for financial support and research grants for E.A.S, A.B. and G.M.F.

\section{REFERENCES}

DYER, A. F., 1994, Natural soil spore banks - can they be used to retrieve lost ferns? Biodiversity and Conservation, 3: 160-175.

DYER, A. F. \& LINDSAY, S., 1992, Soil spore banks of temperate ferns. Am. Fern. J., 82: 89-122.

DYER, A. F. \& LINDSAY, S., 1996, Soil spore banks - a new resource for conservation. In: J. M. Camus, M. Gibby \& R. J. Johns (ed.), Pteridology in perspective, Royal Botanic Gardens, Kew, pp. 153-160.

ERDTMAN, G., 1971, Handbook of palynology (morphology-taxonomy-ecology). An introduction to the study of pollen grains and spores. Munksgaard, Copenhagen, $553 \mathrm{p}$.

ESTEVES, L. M. \& FELIPPE, G. M., 1985, Fotossensibilidade de esporos de pteridófitas dos cerrados. Rev. Brasil. Bot., 8: 219-222.

GIANOTTI, E. \& LEITÃO-FILHO, H. F., 1992, Composição florística do cerrado da Estação Experimental de Itirapina (SP). In: R. Sharif (ed.), Anais $8^{o}$ Congresso Sociedade Botânica de São Paulo, SBSP, Campinas, pp. 21-25.

GOODLAND, R., 1971a, Oligotrofismo e alumínio no cerrado. In: M. G. Ferri (ed.), Simpósio sobre o cerrado Editora Edgard Blücher Ltda. e EDUSP, Belo Horizonte e São Paulo, pp. 44-60.

GOODLAND, R., 1971b, The cerrado oxisols of the Triângulo Mineiro, Central Brazil. An. Acad. Brasil. Ciênc., 43: 407-414.

HAMILTON, R. G., 1988, The significance of spore banks in natural population of Athyrium pycnocarpon and $A$. thelypterioides. Amer. Fern J., 78: 96-104.

LÁQUILA, V. DE \& ESTEVES, L. M., 1997, Estudos morfológicos em gametófitos na Reserva Biológica e Estação Experimental de Mogi-Guaçu. In: Instituto de Botânica de São Paulo (ed.), Resumos, $4^{a}$ Reunião Anual do Instituto de Botânica, Instituto de Botânica, São Paulo, p. 26.
LINDSAY, S. \& DYER, A. F., 1990, Fern spore banks: implications for gametophyte establishment. In: J. Rita (ed.), Taxonomia, biogeografia y conservatión de pteridófitos, Societat d'Historia Natural de les Illes Balears-Institut Menorqui d' Estudis, Palma de Mallorca, pp. 243-253.

MALAVOLTA, E., SARRUGE, J. R. \& BITTENCOURT, V. C., 1977, Toxidez de alumínio e de manganês. In: M. G. Ferri (ed.), IV Simpósio sobre o cerrado: bases para utilização agropecuária, Editora Itatiaia e EDUSP, Belo Horizonte e São Paulo, pp. 207-301.

MILLER, J. H., 1968, Fern gametophytes as experimental material. Bot. Rev., 34: 361-440.

RUGGIERO, P. G. C. \& ZAIDAN, L. B. P., 1997, Estudos de desenvolvimento de Viguiera robusta Gardn., uma asteraceae do cerrado. Rev. Brasil. Bot., 20: 1-9.

SIMABUKURO, E. A., ESTEVES, L. M. \& FELIPPE, G. M., 1993, Fotoblastismo de pteridófitas de mata ciliar. Insula, 22: $177-186$.

SIMABUKURO, E. A., ESTEVES, L. M. \& FELIPPE, G. M.,1998a, Fern spore morphology and spore rain of a preserved cerrado region in south-east Brazil (Reserva Biológica de Mogi-Guaçu, São Paulo). Amer. Fern J. 88: 114-137.

SIMABUKURO, E. A., ESTEVES, L. M. \& FELIPPE, G. M.,1998b, Analysis of a fern spore bank in Southeast Brazil. Hoehnea 25: 45-57.

WESSON, G. \& WAREING, P. F., 1969, The role of light in the germination of naturally occurring population of buried weed seeds. J. Exp., Bot., 20: 402-413.

YBERT, J. P., SALGADO-LABOURIAU, M. L., BARTH, O. M., LORSCHEITTER, M. L., BARROS, M. A. DE, CHAVES, S. A. DE M., LUZ, C. F. P. D. E., RIBEIRO, M., SCHEEL, R. \& VICENTINI, K. F., 1992, Sugestões para padronização da metodologia empregada em estudos palinológicos do quaternário. Rev. Inst. Geológico, SP, 13: $47-49$. 